\title{
INTERAKSI SOSIAL DALAM PELAYANAN AKADEMIK DALAM KEHIDUPAN PENDIDIKAN TINGGI DITINJAU DARI TEORI INTERAKSIONISME SIMBOLIK
}

\author{
Baharuddin
}

\begin{abstract}
Abstrak
Interaksi sosial secara global memberikan gambaran bahwa dalam dunia pendidikan maupun masyarakat luas diperlukan pemahaman yang baik dalam pencapaian kehidupan serta kebaikan bersama. Secara global interkasi yang terbangun dalam dunia pendidikan baik itu dosen, mahasiswa dan karyawan harus serasi sesuai tujuan dari pendidikan tersebut. Pendidikan merupakan upaya pencerdasan masyarakat serta anak bangsa, kedepannya dalam pendidikan ditanamakan aspek yang berkaitan dengan ilmu yang mempelajari makna hubungan antara manusia satu dengan yang lainnya tidak melihat pada perbedaan tetapi mengedepankan persamaan. Metode serta strategi harus tepat digunakan dalam memberikan arahan pada peserta didik. Dalam hubungan masyarakat luas banyak hal-hal yang tidak jelas diungkapkan secara kata-kata (lisan) berangkat dari hal tersebut teori interaksionisme simbolik yang ada harus dipahami sehingga tidak terjadi salah komunikasi atau interkasi terbangun berjalan kurang baik.

Simbol-simbol dari kehidupan harus dijabarkan secara baik sehingga terlihat secara utuh sehingga terbangunlah hubungan yang harmonis dengan sesama manusia, terutama dalam melayanani mahsiswa yang memerlukan bantuan secara cepat dan tepat dilakukan, dalam hal ini penulis melayani mahasiswa yang mau membuat transkip nilai baik sementara maupun transkip nilai akdemik (transkip nilai akhir) setelah ujian skripsi selanjutnya dimasukkan dalam data alumni.
\end{abstract}

Kata Kunci: Interaksi, Pendidikan, Mahasiswa dan Akademik

\section{A. Pendahuluan}

Dalam proses interaksi dalam belajar mengajar, faktor yang sangat penting adalah dosen. Mengapa guru dan dosen dianggap penting di dalam proses tersebut. Dosen dipandang penting Karelna peranannya sebagai pelaksana kurdikulum. Dosenlah yang menentukan esjauh mana kurikulum itu telah berhasil dilaksanakan dikampus. Metode berasal dari bahasa yunani yaitu methodus, meta artinya melalui dan hodos artinya berjalan. Methodos artinya berjalan Malalui atau cara melakukan sesuatu.

Suatu metode yang dilakukan dengan cara memberikan penerangan dan penuturan secara lisan oleh seseorang dosen dalam menyampaikan ibahan pelajaran pada sekelompok mahasiswa. Penggunaan metode tanggung jawab dapat dinilai efektif apabila pelaksanaannya dimaksud untuk: meninjau pel- 
jaran atau ceramah yang lalu, agar siswa dan mahasiswa lebih memahami apa yang telah disampaikan, sehingga mereka dapat melanjutkan pelajaran selanjutnya, menyelingi pembicaraan agar tetap mendapatkan perhatian mahasiswa, atau dengan kata lain untuk mengikut sertakan mereka dan mengarahkan pengamatan dan pemikiran mereka.

Sebelum membahas dari teori interaksionisme simbolik, saya ingin memaparkan secara lebih rinci akan arti dan aplikasi interaksi secara khusus, disini diuraikan contoh interaksi yang dilaksanakan seorang dosen dengan mahasiswa. Bagi seseorang dosen untuk hanya mengutamakan teknik dan metode interaksi. Tidak banyak gunanya mengetahui ciri-ciri sebuah metode diskusi yang baik atau teknik atau syaratsyarat ceramah, apabila ia tidak mengetahui apa yang akan diajarkan. Diskusi dilakukan bukan sekedar berdiskusi, ceramah dan lain-lain teknik interaksi. Diskusi diadakan untuk membahas sesuatu persoalan, suatu bahan pelajaran. Dengan demikian seorang dosen harus mengetahui dan memahami apa yang akan diajarkan kepada mahasiswanya.

Interkasi simbolik ini diusahakan antara individu dengan individu yang melakukan interkasi memahami akan makna simbol-simbol yang ada sehingga penafsiran akan situas serta apa yang diinginkan dapat tercapai dengan baik. Sebagai contoh: lampu jalan, orang paham akan warna merah itu menandakan bahwa semua kendaraan berhenti untuk mendahulu jalur lain dalam melintasi jalan hal ini berlaku untuk yang jalannya lurus dan belok kanan. lampu kuning sebagai tanda berhati-hati dan mau datangnya lampu merah kurang lebih lamanya 10 detik selang waktu tersebut. Lampu hijau petanda untuk pengguna jalan boleh melintasi jalan tersebut. Contoh lain ketika pembicara sedang mengisi suatu acara dia baukbatuk kecil dan kita lihat air minum yang disajikan sudah habis maka itu secara tidak langsung si pembicara tersebut minta tambah air minum atau minta disediakan air minum lagi.

Begitupula dalam memberikan pelayanan akademik kemahasiswa dalam perguruan tinggi harus dengan jeli melihat interaksi yang terbangun karena mahasiswa sangat memerlukan pelayanan prima, cepat dan tepat. Kepuasan mahasiswa dalam pelayanan akademik sangat diperlukan sehingga peningkatan serta pendekatan sosial dan kekeluargaan sangat diperlukan sehingga hubungan antara pelayanan akademik dengan mahasiswa saling memberikan situasi yang menyenangkan. Dalam pembuatan transkip nilai baik itu sementara maupun transkip nilai akhir harus secepatnya diselesaikan karena hal tersebut dapat membantu mereka untuk 
menyelesaikan studi lebih cepat serta merasakan pelayanan yang diberikan sangat memuaskan. Dalam pelayanan akademik terutama dalam pembuatan transkip nilai harus teliti sehingga dapat mengurangi kesalahan serta kekeliruan. Dalam pendataaan alumni harus serius dikerjakan karena tolak ukur dari maju atau suksesnya Fakultas dan jurusan juga dapat dilihat dari keberhasilan alumni yang terserap di dunia kerja tentunya sesuai dengan bidang keilmuan waktu dibangku kuliah.

\section{B. Interaksi Yang Terbangun Antara}

\section{Dosen, Mahasiswa dan Karyawan}

Interaksi merupakan suatu proses hubungan antara dua atau lebih orang, yang melahirkan akan komunikasi diantaranya. Ketika interakasi itu berlangsung maka ada beberapa hal yang melandasinya seperti: (1). orang yang menyampaikan (aktor utama), (2). orang yang menerima (lawan main aktor), (3). media adalah suau tempat atau alat dimana interaksi berlangsung, (4). ada sesuatu pesan hal yang ingin disampaikan, (5). adanya suatu timbal balik dari interaksi yang dibangun.

Dalam Baharuddin (2009 :36) menyatakan bahwa interaksi Sosial akan menyebabkan kegiatan hidup seseorang semakin bervariasi dan kompleks. Jalinan interaksi yang terjadi antara individu dan individu, individu dan kelompok, serta kelompok dan kelompok sangat bersifat dinamis dan mempunyai pola tertentu yang membentuk suatu kehidupan bermasyarakat.

Masyarakat merupakan populasi yang membentuk organisasi sosial yang bersifat kompleks. Meskipun norma, nilai, pranata dan peraturan dimiliki oleh setiap kelompok masyarakat dengan tingkat peradaban berbeda, tidak menjamin setiap anggota masyarakat mengetahui sekaligus menyetujuinya. Kenyataan ini cenderung menyebabkan ketidak teraturan atau konflik di tengah-tengah masyarakat. Hakikat manusia sebagai individu dan makhluk sosial dalam banyak hal akan selaras dan seimbang apabila diatur dan diarahkan sebagaimana mestinya (Baharuddin 2009 :36).

Dengan proses interaksi educatif, tujuan inilah yang menjadi arahan guru dalam melaksanakan kegiatan belajat mengajar, sebab tujuan ini dirumuskan dari segi proses. Sedangkan tujuan lembaga dan tujuan program studi merupakan tujuan pendidikan yang dirumuskan dari segi normatif. Dengan demikian keberhasilan dalam pencapaian tujuan instruksional akan menentukan sekali keberhasilan dalam mencapai tujuan lembaga. Bahan pelajaran dalam proses interaksi belajar mengajar merupakan alat dalam mencapai tujuan pendidikan yang telah dirumuskan. Oleh karena itu bahan pelajaran harus sesuai dengan tujuan yang ingin dicapai. Dosen dan karyawan akademik dalam tugas 
sehari-hari selalu memilih dan menentukan bahan pelajaran dan pelayanan yang harus disampaikan kepada mahasiswa. Pilihan dan putusan dosen dan karyawan tersebut tergantung apa yang dianggap baik dan penting untuk diajarkan dan dilayani menurut pandangan dosen dan karyawan tersebut. Didalam proses interaksi belajar mengajar perlu mempertimbangkan keadaan pelajar, sebelum dosen menyampaikan bahan pelajaran. Pertimbangan ini dimaksudkan agar bahan pelajaran yang disajikan dapa diterima dengan baik. Hal ini berkaitan dengan metodologi. Dengan memahami keadaan pelajar tersebut dapatlah ditentukan cara-cara yang tepat dalam menyampaikan bahan pelajaran (Zuldafrial 2009 :39).

Dalam pelayanan akademik kemahasiswaan harus benar-benar diperhatikan secara baik sehingga mahasiswa merasa terbantu akan pelayanan yang diberikan. Pelayanan akademik harus cepat dan tepat sehingga mahasiswa tidak merasa bosan kalau mau berurusan dengan staf akademik. Hal tersebut benar-benar harus disadari bahwa mahasiswa adalah mitra kerja yang harus dilayani dengan baik. Pembuatan transkip nilai sementara untuk persiapan seminar proposal dan ujian skripsi harus cepat dan tepat sehingga mahasiswa tidak merasa dihambat dan tentunya merasakan puas karena dilayani dengan tutur sapa yang baik, komunikasi baik dan waktu relatif cepat.

Dalam Zuldafrial (2009:41) menyatakan perbedaan-perbedaan individual yang harus diperhitungkan dalam Inter-ksi belajar mengajar dan dalam pelayanan akademik di kelas maupun diruang kerja antara lain adalah sebagai berikut:

1. Perbedaan dalam intelegensi.

2. Peredaan dalam perhatian.

3. Perbedaan dalam pengamatan.

4. Perbedaan dalam sikap.

5. Perbedaan dalam motivasi.

Dalam Zuldafrial (2009:46) menyatakan masalah-masalah yang layak untuk di diskusikan adalah:

1. Menarik minat mahasiswa yang sesuai dengan tarapnya.

2. Mempunyai kemungkinankemungkinan jawaban lebih dari sebuah yang dapat dipertahankan kebenaran jawabannya.

3. Menggunakan metode diskusi ada kebaikan-kebaikan dan kelemahankelemahan.

4. Dalam metode diskusi mahasiuswa dapat secara aktif berpartisipasi dengan mengemukakan pendapat yang disertai alasannya.

5. Mahasiswa dilatih berfikir secara kritis untuk kemudian menentukan sikap menerima, menolak, atau tidak mempunyai pendapat yang dikemukakan oleh temannya. 
6. Berguna untuk kehidupan sehari-hari terutama dalam alam demokrasi.

Untuk memaksimalkan layanan akademik kepada mahasiswa perlu adanya komunikasi langsung atau perlu berdiskusi bahkan sampai pada evaluasi pelayanan. Dalam evaluasi pelayanan akademik kepada mahasiswa tentunya tidak terlepas dari arahan atasan dan pendapat mahasiswa dilihat dari pelayanan yang diberikan. Memang tidak mudah menciptakan iklim kekeluargaan suatu masyarakat kampus dalam memberikan pelayanan akademik kepada mahasiswa, hal ini perlu ketelitian, tepat, cepat dan berbasis keperluan. Mahasiswa sebagai mitra kerja yang sudah membayar uang kuliah sehingga tugas bagi kita sebagai karyawan akademik harus memberikan pelayanan secara prima dan memuaskan, walaupun kata prima dan memuaskan itu sangat relatif tetapi harus diusahakan. Jangan sampai mahasiswa lama kuliahnya gara-gara pelayanan akademik yang lamban apalagi kaitannya dengan pembuatan treanskip nilai sementara maupun akademik yang merupakan syarat untuk seminar proposal dan ujian skripsi. Keberhasilan mahasiswa, karyawan, dosen bahkan sampai pada tingkat institut itu merupakan hasil kerja keras serta upaya peningkatan pelayanan berbasis cepat dan tepat.

Dalam A.M. Sardiman (2008:47) menyatakan situasi dalam interaksi belajar mengajar serta pelayanan akademik juga perlu diperhitungkan situasi tersebut dapatlah ditentukan strategi mengajar dan pelayanan yang tepat dalam rangka mencapai tujuan yang telah ditetapkan. Situasi yang perlu diperhitungkan tersebut meliputi keadaan siswa seperti jumah siswa, perbedaan individu waktu, fasilitas belajar mengajar dan fasilitas pelayanan. Evaluasi atau penilaian merupakan salah satu aspek yang terpenting dalam kegiatan interaksi belajar mengajar. Penilaian dimaksud untuk mengetahui apakah tujuan yang diinginkan dalam proses belajar mengajar dan pelayanan akademik telah tercapai atau belum. Hasil daripada suatu penilaian berfungsi untuk antara lain:

1. Mengetahui kesanggupan mahasiswa dan karyawan, sehingga mahasiswa dan karyawan dapat dibantu memilih jurusan, sekolah atau jabatan yang sesuai dengan bakatnya.

2. Mengetahui sampai sejauh mana mahasiswa itu telah mencapai tujuan pembelajaran dan pendidikan serta pelayanan akademik yang diberikan.

3. Menentukan kelemahan metode mengajar yang dipergunakan oleh dosen. Setiap test atau ujian alat penilaian hasil kerja mahasiswa dan dosen. Hasil ujian yang buruk jangan hanya dicari sebabnya pada mahasiswa tetapi juga pada dosen itu sendiri. 
4. Memberikan petunjuk kepada mahasiswa bagaimana harus belajar. Ada hubungan antara sifat ujian dengan teknik belajar.

5. Memberikan dorongan kepada mahasiswa untuk belajar dengan lebih giat. Mahasiswa yang mendapat nilai kurang diharapkan akan terdorong untuk lebih giat belajar.

Interaksi belajar mengajar sebagai suatu interaksi edukatif yang berlangsung didalam suatu lembaga pendididkan formal selalu terikat pada tujuan pendidikan yang ingin dicapai. Tujuan itu dirumuskan secara sadar untuk membuat warga negara yang dicita-citakan, sebagaimana yang dirumuskan didalam undang-undang yang pendidikan nomor 20 tahun 2003 yaitu bertujuan berkembangnya potensi peserta didik agar menjadi manusia yang beriman dan bertakwa kepada Tuhan yang Maha Esa, berakhlak mulia, sehat, berilmu, cakap, reatif, mandiri dan menjadi warga negera ang demokrasi serta bertanggung jawab. Tujuan tersebut merupakan tujuan akhir dari suatu proses intraksi belajar mengajar yang berlangsung di sekolah, tujuan ini dikenal dengan tujuan pendidikan nasional.

Di dalam proses interaksi beajar mengajar selalu terdapat faktor tujuan sebagaisasaran dari kegiatan belajar mengajar, bahan pelajar yaitu materi yang disampaikan sebagai alat mencapai tujuan, dosen yaitu orang yang bertanggung jawab terhadap keberhasilan dari suatu proses pembelajaran, siswa yaitu peserta didik yang mendapatkan pengajaran, yaitu cara yang dilakukan guru dalam menyampaikan bahan pelajaran, situasi yaitu suasana mana proses intraksi belajar mengajar itu berlangsung dan evaluasi yaitu penilaiyan yang dilakukan oleh guru untuk mengetahui kebershasilan proses belajar mengajar.

Pelayananan akademik kemahasiswa harus sesuai aturan dan diusahakan secara maksimal supaya bisa dilayani dengan baik dan mahasiswa yang dilayani merasakan kepuasan. Dalam keseluruhan proses pendidikan dan pengajaran di perguruan tinggi berlangsung interaksi dosen dan mahasiswa dalam proses belajar mengajar yang merupakan kegiatan paling pokok. Jadi proses belajar mengajar merupakan proses kegiatan interaksi antara dua unsur manusiawi yakni maahsiswa sebagai pihak yang belajar dan pengajar sebagai pihak yang mengajar, interaksi belajar mengajar dosen berperan sebagai pembimbing, dosen memberikan motivasi agar terjadi proses interaksi dan sebagai mediator dan proses belajar mengajar, langkahlangkah yang dilaksanakan sesuai dengan prosedur yang sudah ditentukan. Selanjutnya pada tahap akhir pembuatan transkip nilai untuk keperluan penyelesaian studi juga menjadi sangat 
penting diperhatikan karena mahasiswa harus dibantu dan diarahkan serta diberikan pelayanan semaksimal mungkin dalam pembuatan transkip nilai dan selanjutnya didata sebagai alumni keetika sudah ujian skripsi.

Keterampilan interaksi dalam proses belajar mengajar pada dasarnya merupakan kemampuan dosen dalam menyampaikan materi pelajaran kepada mahasiswa agar mudah difahami sehingga tujuan pembelajaran dapat tercapai sesuai dengan apa yang telah dirumuskan dan untuk mencapai tujuan tersebut guru harus terlebih dahulu menyiapkan bahan pelajaran yang akan disampaikan, menentukan metode pengajaran yang akan digunakan, memilih media pengajaran yang tepat, dengan begitu hasil pengajaran yang diperoleh akan cukp baik.

Masyarakat merupakan populasi yang membentuk organisasi sosial yang bersifat kompleks. Meskipun norma, nilai, pranata dan peraturan dimiliki oleh setiap kelompok masyarakat dengan tingkat peradaban berbeda, tidak menjamin setiap anggota masyarakat mengetahui sekaligus menyetujuinya. Kenyataan ini cenderung menyebabkan ketidak teraturan atau konflik di tengah-tengah masyarakat. Hakikat manusia sebagai individu dan makhluk sosial dalam banyak hal akan selaras dan seimbang apabila diatur dan diarahkan sebagaimana mestinya. Setiap masyarakat akan mengalami perubahan dan dinamika sosial, baik di desa maupun di kota. Perubahan dan dinamika itu merupakan akibat dari adanya interaksi antar manusia dan antar kelompok yang menyebabkan perubahan dan dinamika sosial.

Perubahan dan dinamika yang terjadi di masyarakat bisa berupa perubahan nilai-nilai sosial, norma-norma yang berlaku dimasyarakat, pola prilaku individu dan organisasi, susunan lembaga kemasyarakatan, lapisan-lapisan atau kelas-kelas dalam masyarakat, kekuasaan, wewenang, dan interaksi sosial. Dengan kata lain perubahan sosial bisa meliputi perubahan organisasi sosial, status, lembaga dan struktur sosial masyarakat. Perubahan sosial adalah segala perubahan pada lembagalembaga kemasyarakatan didalam suatu masyarakat yang mempengaruhi sistem sosialnya, termasuk didalamnya nilainilai, sikap, dan pola perilaku di antara kelompok-kelompok dalam masyarakat.

Proses pendidikan berlansung tidak tanpa sadar atau tujuan. Pengajaran merupakan proses yang berfungsi membimbing pelajar didalam kehidupan yakni membimbing memperkembangkan diri sesuai dengan tugas-tugas perkembangan yang harus dijalani oleh siswa itu. Tugas perkembangan tersebut mencakup kebutuhan hidup baik sebagai individu, maupun sebagai masyarakat. Bilamana ditinjau secara luas akan 
nampak jelas bahwa proses kedewasaan manusia yang hidup dan berkembang adalah manusia yang selalu berubah dan perubahan itu adalah hasil belajar. Hanya soalnya tidak semua peristiwa belajar itu berlangsung secara sadar dan terarah. Malahan yang galinya lebih banyak halhal yang dipelajari manusia dengan tidak sadar dan berencana yang sadar dan terarah. Menyadari perubahan yang tak disadari dan tak diarahkan lebih banyak memberi kemungkinan perubahan tingkah laku yang berada diluar titik tujuan, setidak-tidaknya sebagian kehidupan itu dibimbing secara sistimatik.

Keberhasilan fakultas sebagai unit kerja dalam perguruan tinggi sebagai lembaga pendidikan sangat ditentukan oleh mutu pelayanan yang diberikan, dimana pelayanan yang bermutu dapat diidentifikasi melalui kepuasan pengguna jasa, dalam hal ini adalah mahasiswa. Kepuasan adalah hasil dari pemenuhan konsumen bahwa pelayanan telah memberikan tingkat kenikmatan dimana tingkat pemenuhan ini bisa lebih. Untuk mencapai tingkat kepuasan yang tinggi, diperlukan adanya pemahaman apa yang diinginkan konsumen, dengan mengembangkan komitmen setiap orang yang ada dalam lembaga untuk memenuhi kebutuhan konsumen.

Mutu atau kualitas dapat diartikan sebagai suatu kondisi dinamis yang berkaitan dengan produk, jasa, manusia, proses dan lingkungan yang memenuhi dan melebihi harapan. Mutu berkaitan dengan pencapaian standar yang diharapkan, dimana harus benar-benar dapat memahami apa yang dibutuhkan konsumen atas suatu produk yang akan dihasilkan.

Mutu pelayanan akademik yang baik didasarkan pada kinerja berbagai kalangan baik tenaga pengajar, tenaga administrasi bahkan hingga petugas kebersihan. Tenaga pengajar (dosen) harus memberikan jasa pengajaran yang berkualitas kepada peserta didik. Tenaga administrasi harus mendukung dan melayani kebutuhan mahasiswa yang berkaitan dengan administrasi sebaik mungkin sehingga mahasiswa mampu melakukan aktivitas akademiknya. Demikian pula dengan petugas perlengkapan dan kebersihan, petugas perlengkapan harus mempersiapkan sarana penunjang proses belajarmengajar yang dibutuhkan dosen dan mahasiswa, petugas kebersihan harus senantiasa menjaga kebersihan fasilitas sehingga tidak mengganggu jalan proses belajar-mengajar di lingkungan kampus.

Perguruan tinggi atau lebih khususnya pada tingkat fakultas sebaiknya memberikan pelayanan akademik yang memuaskan dan menunjang kelancaran proses belajarmengajar. Pelayanan akademik yang baik akan menghasilkan output yang baik pula dan secara tidak langsung akan memberikan manfaat yang signifikan 
terhadap keberlangsungan pendidikan tinggi.

Interaksi yang terjalin antara pegawai administrasi, dosen, dan mahasiswa di perguruan tinggi sangat dipengaruhi oleh bagaimana persepsi mahasiswa terhadap lingkungan pendidikan tersebut. Lingkungan pendidikan tersebut meliputi sarana dan prasarana sebagai pendukung kegiatan proses belajar-mengajar, dosen sebagai pendidik, dan tenaga pendukung lain yang ada dalam lingkungan pendidikan tersebut. Persepsi dipengaruhi oleh karakteristik pribadi, seperti sikap, motivasi, kepentingan atau minat, pengalaman dan pengharapan. Persepsi seseorang terhadap suatu obyek akan berbeda-beda, oleh karena itu persepsi mempunyai sifat yang subyektif. Demikian pula halnya, persepsi mahasiswa terhadap suatu mutu pelayanan pendidikan antara satu mahasiswa dengan mahasiswa lain akan berbeda-beda, sehingga hal ini akan menyebabkan perbedaan pula dalam dorongan/motivasi pada mahasiswa tersebut untuk melakukan aktifitas belajar.

Selain dari pada itu juga tidak cukup, bagi seseorang guru untuk hanya mengutamakan teknik dan metode interaksi. Tidak banyak gunanya mengetahui ciri-ciri sebuah metode diskusi yang baik atau syarat-syarat ceramah, apabila ia tidak mengetahui apa yang akan diajarkan. Diskusi dilakukan bukan sekedar berdiskusi, begitu pula sosiodrama, ceramah dan lain-lain teknik interaksi. Diskusi diadakan untuk mimbahas sesuatu persoalan, suatu bahan pelajaran. Dengan demikian seorang guru harus mengetahui dan memahami apa yang akan diajarkan kepada siswasiswinya.

Dalam pendidikan terdapat dua jenis proses yaitu proses pendidikan dan non pendidikan. Proses pendidikan sering juga disebut proses teknis sedangkan non pendidikan sering disebut non tehnik. Administrasi tergolong proses non teknis yang pada dasarnya berfungsi agar proses tehnik berjalan dengan mulus. Fungsi proses administrasi itu adalah merancang, mengatur, mengkoordinasikan, menyediakan fasilitas, mengarahkan, memperbaiki proses teknis

\section{Interaksionalisme Simbolik Dalam Aplikasi Pelayanan Akademik} Interaksonalisme simbolik merupakan dasar pemikiran George Ritzer (1994) ada 2 pemikiran pokok yaitu pemikiran filsafat pragmatism dan pemikiran behaviorisme psikologi (Agus Salim 2008: 9). Teori Interak-sonalisme simbolik ini merupakan sisi lain dari pandangan yang melihat individu sebagai produk yang ditentukan oleh masyarakat. Teori ini berkembang pertama kalinya di Universitas Chicago dan dikenal sebagai aliran Chicago, dua orang tokoh besarnya 
adalah John Dewey dan Charles Horton

Cooley (C. Dewi Wulandari 2009: 194).

Interaksonalisme simbolik berasal dari pemikiran Weberian, yang bertolak dari kegiatan interpretif terhadap subjek individu.Teori interaksonalisme simbolik menggunakan perspektif pendekatan fenomenologi yang menempatan bahwa kesadaran manusia dan subjektif sebagai fokus untuk memahami tindakan sosial. Interaksonalisme simbolik dalam sosiologi berfokus pada individu, dengan demikian berusaha meng-analisis interaksi antara individu pada tataran mikro. Para ahli interaksonalisme yang lahir dari aliran Chicago School melihat bahwa individu merupakan objek yang bisa secara langsung ditelaah dan dianalisis melalui interaknya dengan individu yang lain. Pencetus gagasan Interaksonalisme simbolik Herbert Blumer (1969) menyatakan ada tiga premis utama yang dilontarkan dalam kajian ini (Agus Salim 2008: 10).

Interaksonalisme simbolik telah diperhalus untuk dijadikan salah satu pendekatan sosiologi oleh Herbert Blumer dan Goeorge Herbert Mead, yang berpandangan bahwa manusia adalah individu yang berpikir, berperasaan, memberiakn pengertian kepada setiap keadaan, yang mealahirkan reaksi dan interpretasi symbol-simbol atau komunikasi bermakna yang dilakukan melalui gerak, bahasa, rasa simpati, empati, dan melahirkan tingkah laku lainnya yang menunjukkan reaksi atau respons-respons yang diberikan dipengaruhi oleh karekteristik yang dimiliki individu, seperti status sosial, situasi relasional dan motivasi yang dimiliki (Agus Salim 2008: 11).

Kalau kita perhatikan rumusan administrasi pendidikan sesungguh-nya dapat dibayangkan mengenal apa yang menjadi tujuan administrasi itu. Tujuannya tidak lain adalah agar semua kegiatan itu mendukung tercapainya tujuan pendidikan atau denga kata lain administrasi di gunakan didalam dunia pendidikan adalah agar tujuan pendidikan tercapai. Sehingga dalam interaksi simbolik kita dapat memahami karekteristik mahasiswa yang amau kita layani sehingga membuat suasa yang nyaman dan aman.

Bila kita bicara mengenai layanan administrasi pendidikan atau kepuasan mahasiswa atas layanan yang diberikan, maka kita berbicara mengenai kreatifitas. karena kreatifitas memungkinkan sebuah organisasi atau dalam hal ini adalah administrasi pendidikan dapat menangani dan memecahkan masalah-masalah yang sedang maupun yang akan dihadapi dalam praktik administrasi pendidikan sehari-hari. Untuk mewujudkan dan mempertahankan kepuasan terhadap mahasiswa maka adminsitrasi pendidikan harus melakukan tiga hal; pertama, mengidentifikasi setiap masalah yang dihadapi mahasiswa, kedua; memahami 
tingkat harapan atas kualitas dan ketiga; memahami strategi kualitas layanan.

Dalam hal ini diharapkan antara dua individu yang melakukan interaksi harus saling pengertian atau mengerti makna simbol yang disampaikan. Hal ini digunakan sebagai isyarat dari sikap manusia untuk meminta baik itu pertolongan atau minta sesuatu. Karena interaksi ini tidak berbentuk kata lebih Identik dengan pernyataan dari tingkah laku maka simbol-simbol yang dimunculkan tidak akan dipahami bagi orang buta dan tuli. Karena dalam membangun interaksi harus melihat dengan jelas dan paham akan apa maksud simbol yang diberikan.

Menurut Agus Salim (2008: 11) menyatakan ciri utama Interaksonalisme simbolik adalah meniadakan konsep masyarakat, negara dan institusi sosial yang lain karena dianggap hanyalah sebagai abstarksi belaka. Keberadaan konsep masyarakat, negara dan institusi sosial hanyalah merupakan kumpulan abstraksi tertentu, sehingga hamper tidak berarti pada tataran mikro.

Menurut Agus Salim (2008 : 1314) menyatakan secara garis besar Interaksonalisme simbolik oleh Deddy Mulyana (2001: 71-73), menjadi tiga langkah utama. Pertama, individu merespons suatu situasi khas yang bernama situasi simbolik. Individu merespons lingkungan mereka termasuk objek fisik (benda) dan objek sosial (perilaku manusia) berdasarkan maknya yang dikandung kompenen-komponen lingkungan tersebut bagi mereka.Kedua, makna adalah produk interaksi sosial karena makna tidak melekat pada objek, melainkan dinegosiasikan melalui penggunaan bahasa.

Secara umum ada 3 hal penting dalam mempelajari aliran berpikir Interaksonalisme simbolik (1) Memusatkanperhatian antara actor dengan dunia nyata; (2) meamndang-baik aktor maupun dunia nyata-sebagai proses dinamis dan bahkan sebagai struktur yang statis; (3) Kemamouan aktor untuk menafsirkan dunia nyata (Agus Salim 2008 :20).

Dalam Agus Salim (2008: 25) John Dewey mengemukakan teori belajar yang mengedepankan impuls-impuls ynag telah dipelajari sehingga membentuk sikap yang menjadi pilihan seseorang. Masalah yang timbul adalah kenyataan bahwa ada sebagian orang yang tudak membutuhkan waktu lama untuk mempelajari aspek sumber belajar, tetapi ada sebagian lagi yang membutuhkan waktu lama untuk mempelajari sumber informasi belajar yang datang dari luar individu.

Menurut Agus Salim (2008: 40-41) Harbert Blumer menyatakan dalam teorinya: (a) manusia bertindak terhadap sesuatu berdasarkan makna-makna yang ada pada sesuatu itu bagi mereka, (b) makna itu diperoleh dari hasil interaksi sosial yang dilakukan dengan orang lain, 
(c) makna-makna tersebut disempurnakan di saat proses interaksi sosial yang sedang berlangsung.

Penerapan sistem administrasi akademik pada aspek pelayanan administrasi akademik menciptakan citra baru bagi administrasi akademik fakultas, diantaranya adalah sistem pelayanan yang lebih cepat dan akurat, penyediaan sarana prasarana yang memadai, dan penyelesaian setiap masalah yang dihadapi tiap mahasiswa dengan baik dan komprehensif. Ketika semua dilakukan dengan baik dan proporsional, maka akan semakin baik pula citra administrasi akademik dibenak mahasiswanya dan juga lembaga yang menaunginya.

Menurut Agus Salim (2008: 41-42) Harbert Blumer menyatakan inti dari pemikirannya mengenai Interaksonalisme simbolik dapat disadur dari kajian Poloma (1984) sebagai berikut:

1. Masyarakat terdiri dari manusia yang berinteraksi.

2. Interaksi berhubungan dengan kegiatan manusia lainnya.

3. Objek yang tidak mempunyai makna yang intrinsik lebih merupakan produk interaksi simbolis.

4. Manusia tidak hanya mengenal objek eksternal, namun mereka juga dapat mengenal dan melihat dirinya sebagai objek.

5. Tindakan manusia adalah tindakan interpretative yang dibuat oleh manusia.
6. Tindakan tersebut saling dikaitkan dam disesuaikan oleh anggota-anggota kelompok.

Dalam C. Dewi Wulandari (2009: 194) Margaret M. Poloma (1992:277) menyatakan teori Interaksonalisme simbolik merupakan konseptualisasi diri dianggap sedang mengalami proses dan tidak benar-benar menyesuaikan diri dengan apa yang dicita-citakan yaitu manusia kaum fungsionalis yang terlalu disosialisir. Orang menerapakan makna subjektif ada dunia objek mereka, dari pada hanya menerima penafsiran realitas objektif yang telah dirancang sebelumnya.

Interaksonalisme simbolik juga dilihat dalam interkasi manusia dengan lingkungan hidup disekitarnya. Kepedulian manusia pada lingkungan sangat penting sekali dalam upaya menciptakan keharmonisasian dalam sebuah tatanan kehidupan yang dijalani.Sehingga manusia yang berada dilingkunga itu memiliki fungsi serta makna hidup maka harus bisa melestarikan lingkungan.

Hovland dalam Onong Uchjana Effendy (2001: 10) mengatakan bahwa komunikasi adalah proses mengubah perilaku orang lain (communication is the process to modify the behavior of other individuals). Dance dalam Alo Liliweri (1997: 5) mengatakan bahwa definisi komunikasi itu: 
1. Komunikasi sebagai aktivitas dari suatu pihak.

2. Aktivitas yang datang dari pihak lain/mempengaruhi.

3. Komunikasi yang menekankan hubungan.

4. Komunikasi yang menekankan sharing atau pemilikan.

5. Komunikasi sebagai transmisi informasi.

6. Komunikasi sebagai penggunaan lambang.

Komunikasi didefinisikan sebagai apa yang terjadi bila mana diberikan kepada suatu perilaku. Sebagai contoh sederhana bila diperhatikan perilaku seseorang dan memberinya makna, komunikasi telah terjadi terlepas dari apakah sesorang menyadari perilaku atau tidak dan menyenangkan atau tidak. Bila memikirkan hal ini harus menyadari bahwa tidak mungkin bagi seseorang untuk tidak berperilaku. Setiap perilaku memiliki potensi komunikasi (Dedy Mulyana dan Jalaluddin Rahmat 2001: 13).

Dalam Onong Uchjana Effendy $(2001: 11,16)$ dikatakan bahwa proses komunikasi terbagi menjadi dua tahap, yakni secara primer dan secara sekunder. Dapat di jabarkan secara singkat akan proses primer dan sekunder itu seperti:

a. Proses komunikasi secara primer adalah proses penyampaian pikiran dan atau perasaan seseorang kepada orang lain dengan menggunakan lambang (simbol) sebagai media. Lambang sebagai media primer dalam proses komunikasi adalah bahasa, kial, isyarat, gambar, warna dan lain sebagainya yang secara langsung mampu "menerjemahkan" pikiran dan atau perasaan komunikator kepada komunikan.

b. Proses komunikasi secara sekunder adalah proses penyampaian pesan oleh seseorang kepada orang lain dengan menggunakan alat atau sarana sebagai media kedua setelah memakai lambang sebagai media pertama. Seorang komunikator menggunakan media kedua dalam melancarkan komunikasinya karena komunikan sebagai sasarannya berada di tempat yang relatif jauh atau jumlah banyak. Surat, telepon, teleks, surat kabar, majalah, radio, televisi, film dan banyak lagi adalah media kedua yang sering digunakan dalam komunikasi.

Komunikasi yang terbangun ditengah masyarakat yang beruoa komunikasi verbal adalah suatu interaksi dimana manusia dapat menjadikan simbol dari setiap tingkah laku menjadi makna. Memahami komunikasi secara keseluruhan berarti Interaksonalisme simbolik yang disampaikan oleh peran akan aktornya dimengerti akan makna yang disampaikan.

Membangun komunikasi yang efektif dengan mahasiswa pada bentuk 
pelayanan akademik itu harus dilakukan secara maksimal sehingga hasil didapatkan dengan kepuasan dari layanan. Pembuatan transkip nilai dan pendataan alumni yang penulis kerjakan sebagai staf akademik di fakultas sangat berorientasi kekeluargaan dan asas kebutuhan saling membantu sehingga dengan demikan kita sebagai pelayan merasa nyaman tidak terbebani dengan tugas dan kewajiban juga mahasiswa merasa sangat terbantu dan merasakan pelayanan prima, cepat dan tepat.

Mealayanai mahasiswa dalam pelayanan akademik benar-benar harus dikerjakan secara serius dan maksimal sehingga kemajuan lembaga serta institut dapat tercapai. Semua proses pelayanan akademik berjalan lancar dan benar secara aturan dan peraturan. Bentuk pelayanan juga harus dilakukan evaluasi baik melalui baca buku maupun melibatkan atasan langsung sebagai pengarah serta evaluasi dan mahasiswa objek yang dilayani.

\section{Kesimpulan}

Dari pembahasan tulisan ini, dapat disimpulkan bahwa: dalam mengelola interaksi belajar mengajar dosen harus memiliki kemampuan mendesain program, menguasai materi pelajaran. mampu menciptakan kondisi kelas yang kondusif, terampil memanfaatkan media dan memilih sumber, temahami cara atau metode yang digunakan, memiliki keterampilan mengkomunikasikan program, serta memahami landasan-landasan pendidikan sebagai dasar pertindak, mengajar bukanlah kegiatan memindahkan pengetahuan dari dosen ke mahasiswa, melainkan suatu kegiatan yang memungkinkan mahasiswa membangun sendiri pengetahuannya, mengajar berarti partisipasi dengan mahasiswa dalam membentuk pengetahuan, proses belajar harus tumbuh dan berkembang dari diri anak sendiri, dengan kata lain mahasiswa yang harus aktif belajar sedangkan dosen bertindak sebagai pembimbing dan berdasarkan orientasi proses belajar mengajar mahasiswa harus ditempatkan sebagai sujek belajar yang sifatnya aktif.

Pelayanan akademik harus berbasis kekeluargaan dan standar mutu, sehingga mahasiswa merasakan kepuasan akan pelayanan yang diberikan oleh staf akademik. Dalam pelayanan pembuatan trnskip nilai dan pendataan alumni dikerjakan secara cepat dan tepat yang berbasis pelayaan prima. Hal tesebut dilakukan untuk membantu mahasiswa dalam percepatan penyelesaian studi, karena transkip nilai itu untuk syarat seminar proposal dan ujian skripsi sehingga pelayanan ini harus benarbenar serius dan maksmila sehingga tidak menghambat proses penyelesaian studi.

Dalam keseluruhan proses pendidikan dan pengajaran di perguruan tinggi berlangsung interaksi dosen, 
karyawan akademik dan mahasiswa dalam proses belajar mengajar yang merupakan kegiatan paling pokok. Pelayanan akademik yuang diberikan berbasis kekeluargaan dan komunikasi efektif supaya terciptaan iklim yang hormanis serta saling menghargai dan saling memerlukan. Keterkaitan antara pelayanan akademik dengan kelangsungan penyelesaian studi mahasiswa sangat erat sekali karena keduanya harus berjalan sejajar dan saling bahu membahu, sehingga sinergifitas keberhasilan dapat tercapai dengan baik dan normal sesuai harapan dan aturan.

\section{Daftar Pustaka}

A.M. Sardiman. 2008. "Interaksi Motivasi Belajar Mengajar". Jakarta: PT. Rajagrafindo Persada.

Agus Salim. 2008. "Pengantar Sosiologi Mikro". Yogyakarta: Pustaka Pelajar.

Alo Liliweri. 1997. "Komunikasi

Antarpribad"i. Bandung: PT. Citra Aditya Bakti

Baharuddin. 2009. "IImu Sosial Budaya Dasar". Pontianak: Pustaka Abuya.

Baharuddin. 2009. "Pendidikan Kependudukan Lingkungan Hidup". Pontianak: STAIN Press Pontianak.
C. Dewi Wulandari. 2009. "Sosiologi Konsep dan Teori". Bandung: Refika Aditama.

Dedy Mulyana dan Jalaluddin Rakhmad. 2001. "Komunikasi Antar Budaya". Bandung: Remaja Rosdakarya.

K. J. Veeger. 1993. "Realitas Sosial: Refleksi Filsafat Sosial Atas Hubungan individu-masyarakat Dalam Cakrawala Sejarah Sosiologi”. Jakarta: PT Gramedia Pustaka Utama.

Onong Uchyana Effendy. 2001. "IImu Komunikasi”. Bandung: Remaja Rosdakarya.

Zuldafrial. 2009. "Belajar Interaksi Belajar Mengajar". Pontianak: STAIN Press Pontianak. 